\title{
College students' English pragmatic competence analysis and college
}

\section{English teaching}

\author{
Shuo Chi
}

Tonghua Normal University, Tonghua, Jilin, 134001

\begin{abstract}
Key words: college students; English teaching; Pragmatic competence
\end{abstract}
\begin{abstract}
To enhance language pragmatic competence is the main purpose of the college students' language learning, the importance of the English education system in colleges and universities is obvious. Correct English form does not mean that can speak proper English, lack of pragmatic competence will cause pragmatic failure. In college English teaching to cultivate and improve college students' English pragmatic competence, pragmatic competence connotation to the paper, on the basis of analysis to enhance the feasibility and importance of pragmatic competence, understand the actual situation of present college students' English pragmatic competence, and then work out the improvement of the pertinence, strong operational strategy. College teachers should not only attach importance to the interpretation of basic knowledge of English, also attaches great importance to the cultivation of pragmatic competence, promote the improvement of students' comprehensive ability.
\end{abstract}

\section{Introduction :}

In 2004 the ministry of education in our country college English teaching requirements, further defined the new requirement and new objective of college English education, especially put forward to enhance the ability of college students to use English to achieve communicative purpose Communication system, the composition of pragmatic competence is an important link, has become the emphasis and difficulty of college English education..However, for quite a long time, affected by the exam-oriented education, English teaching to cultivate students' ability in grammar, and ignore the cultivation of pragmatic competence and communicative competence. College students pragmatic competence significantly lagged behind the other. According to the relevant departments according to a survey, college students' language competence and pragmatic competence, not form a direct part of the students has a special solid language foundation, but in the intercultural communication, due to differences in national culture, customs, and using the wrong language use, the situation with the college English teaching mode, teaching idea has a close relationship.

\section{College students to enhance the feasibility and the importance of pragmatic competence in English}

English pragmatic competence refers to the communication, the listener on the premise of cognitive context, understand the speakers intention and ideas, and can accurately stated his intention and the idea of a kind of ability. College English teaching process, is the process of training this ability.

Colleges and universities to carry out the aim and purpose of foreign language education is to let the students have in various occasions written and oral language ability to communicate with others, it belongs to the part of communicative competence, has key effect to understand the 
language and express ideas. The actual situation of foreign language teaching in colleges and universities and the problems that the conduct pragmatic education, enhance the importance of college students' English pragmatic competence. At present, China's English learning environment, the lack of real language environment, affects the sustained, stable development of college students' pragmatic competence.The lack of English pragmatic competence will cause pragmatic failure.

Many experts and scholars abroad through a large number of investigation and analysis to study how to enhance learning a second language students' pragmatic competence research: Although some pragmatic knowledge teaching is difficult, but many of the target language can be used in teaching. On the whole, the teacher teach English pragmatic knowledge can promote the development of students' pragmatic competence. Some scholars in China also attaches great importance to the research method of training students' pragmatic competence, think cultivating pragmatic competence has strong feasibility and operability.

\section{College English teaching and the present condition of the college students' English pragmatic competence}

At present, our country college students' English pragmatic ability is weak, often appear mistakes in cross-cultural communication, influence the communication effect, concentrated expression in three aspects.

Language pragmatic mistakes is to point to, in the special language environment is hard to accurately illustrate their ideas, or to apply Chinese language habits in English, let the other side is difficult to understand or pragmatic mistakes caused by misunderstanding College students to apply Chinese corresponding word or Chinese pinyin language strategies in English, because both the differences of pragmatic meaning and mistakes. For example, the English spoken in college students' contrary to the language habits of the english-speaking countries; Understand the literal meaning, don't understand the real intention of the speaker; Don't know the correct expression form, the application of a Chinese habit in English; Can't distinguish synonymous structure in various situations, how to use; Free to use complete sentences, not pay more attention to their special connotation under the special environment and so on. [3]。 In the pragmatic language mistakes appeared in the process of communication is obvious, as long as the note will be found. In class we often use "Good morning the teacher" to greet the teacher, is clearly chinglish, "the teacher" is a professional name in English, cannot be applied in the call.

Social pragmatic failures are due to not knowledge culture connotation, choice of language form error. This involves the obligations and rights of people, feeling of interpersonal relationship, etc., and is directly related to people's thoughts, feelings, values, and in social activities is difficult to capture and detect, students because they don't understand the English national customs, religious beliefs, cultural connotation and social pragmatic failures. Polite expressions, for example, the Chinese usually say "hard" to its guests coming from afar, if the guest says in English "I am afraid you may feel tired", the other party will feel unknown so, in this situation should use "Nice to meet you" language to exchange greetings. Like when people praise you, Chinese people usually choose a modest answer, and by an Englishman, direct answer "Thank you".

Because in college English teaching, there is tendency to downplay the heard, attach importance to reading and writing, many students, speaking, reading and writing are significantly higher than listening and speaking skills. Some students had to pass the English test band 4 and band 6, but its use English to communicate with foreigners, not don't understand just don't know how to communicate, manifests the student will not use the problems, the serious influence college students' English pragmatic competence and intercultural communication ability. 


\section{To improve college English teaching, enhance students' English pragmatic competence strategy}

Since the 1980 s, China's education and academic stress the study of intercultural communication, culture, education, clear cultivating college students' pragmatic competence in college English education status. But pragmatic teaching did not achieve the desired effect, how to strengthen college students' English pragmatic competence is must solve the problem. To English environment in our country as the foothold, into the pragmatic competence education in English teaching, improve students' cross-cultural communication ability.

Universities should break through the old way of teaching, will be closed postures, open teaching change teaching methods. The quality of teaching according to the general rule of language learning. In the teaching process to prevent two tendencies: the first is to avoid language lesson become boring knowledge class, only attach importance to college students read the article number and master the grammar and vocabulary, ignoring the cultivation of students' pragmatic competence. As is known to all, college English teaching is not only to be familiar with the language, also want to understand the culture, and language is part of culture. Ability to use language is not included in the language, but also covers language knowledge[4]。 Teachers should not only explain language knowledge, but also the communication principle and communication culture, teach students about words, sentences use social background and conditions.

The second is to avoid English reading and writing, listening and speaking skills appear disjointed phenomenon. Ability to use language usually belongs to the comprehensive ability, including reading, listening, speaking, writing and so on four aspects of skills. In the process of students ability training, although undertake to the student training respectively, but particularly close connection between different skills. Such as grammar skills affect the ability of writing and speaking, listening teaching and communication law has a close relationship between, etc.

College English teachers bear the important task of teaching, its pragmatic consciousness of high and low has a direct effect on whether students have pragmatic competence, so to enhance teachers' pragmatic ability is particularly important. Teachers only gradually improve English pragmatic competence, to cultivate and enhance students' pragmatic competence. Colleges and English teachers should actively change the teaching idea, the English teaching focus on the cultivation of students' language ability from the traditional to the cultivation of pragmatic competence, to guide the English teachers study pragmatic theory, and through the theory to guide teaching.

The cultivation of the college students' pragmatic competence, the key is to cultivate the consciousness of social pragmatics and pragmatic language two, avoid the mistakes that should not be. Teachers should make students understand that learning English is to achieve intercultural communication, should not only master the language skills and language knowledge, also should have pragmatic ability [5]。 The teacher must the cultural content which likes by the student be an objective point, transfers its study interest, lets the student understand the more British and American culture content, enhances its cultural connotation, then realization culture communication and exchange. To add the English name in the textbooks, goodbye, compliments, thanks, greetings, such as knowledge, after the students' language level gradually improve, also can increase the religion, aesthetics, philosophy, anthropology, sociolinguistics, and other fields of knowledge, attach importance to cultural annotations, let students understand the cultural knowledge and language knowledge is an integral whole, to synchronize learning and development.

Move more often practice, turn gradually, language ability of pragmatic competence

A long time, China's college English education often choose teaching mode with teachers as the core, in the process of classroom teaching, students accept knowledge in a passive position. The 
key to the reform of college English teaching is to change teaching mode, with an emphasis on learning, meet the demand of students, and strengthen students' comprehensive language skills 。 College students must learn in application of English learning, memory and improve. Practice ear, often speak and write more, we can not only enhance the capacity of language, also can improve the pragmatic competence. Practice ear is emphasis on listening, listen to don't understand is difficult to communicate, but enhance the hearing ability is influenced by many factors, both psychological factors, there is also a language, vocabulary, grammar, language factors such as voice, only listen to enhance the hearing ability; "Said" is the general expression of any language, often say English can effectively cultivate students' pragmatic competence, side, said, the side with, use master the knowledge of English to communicate, can better reinforce learning effect; How to write is a college student to get into the habit of writing in English and record at any time.

The second classroom is an effective way to enhance the students' pragmatic competence

University English courses with a strong practicality, students continued participation and practices in order to enhance English language skills[6]。 Because of the lack of good English learning environment in our country, the students are difficult to massive exposure to English, so the classroom become college students' English learning and contact situations effectively。College English teaching to arrange, the careful design, can make scene, creating context, lets the student in the more real and natural environment in the pragmatic study, can also use books, video, audio, film, multimedia, network and so on, to let the students know more about English country local conditions and customs, increasing the quality of classroom teaching. Meanwhile, also opened a second classroom, based on the content, various types of extracurricular activities, such as speaking competition, stories, one-act play, short plays and other activities, through the English corner, English salon, English broadcast platform and create a harmonious atmosphere, good language, improving the enthusiasm, initiative and creativity of the students participating in activities, and to enhance students ' pragmatic competence in English.

\section{Conclusion}

Compared with foreign research, less pragmatic competence study of classroom teaching quality in our country, there are no established stable, system problem domain. Need to learn and draw lessons from foreign research methods and research results, but in college English teaching practice in our country as the foothold, theory and application of research to improve students' pragmatic competence strategy. On the carrier of teaching outline, from the perspectives of teaching materials, teachers, students, efforts, through practice, classroom activities, learn more pragmatic training way such as the second classroom, overcome despise pragmatics in college English teaching, attach importance to the problem of language, improve students' pragmatic competence and intercultural communicative competence.

\section{Acknowledgement}

This work was supported by the "13th Five-Year " Social Science Research Project, Education Department of Jilin Province 2017: Research on the Cultivation of Students' Pragmatic Competence in Provincial Universities from the Perspective of Internationalization, 2017 (JJKH20170450SK)

\section{Reference:}

[1] Yu Yong.Study on the cultivation of pragmatic competence of college English classroom from the perspective of multiculturalism [J]. Journal of Hubei Correspondence University, 2017, (04): 
149-150.

[2] Liu Qiao-xiang. On the cultural infiltration in college English teaching [J]. Journal of Hubei Correspondence University, 2017, (02): 171-172.

[3] Hu Xiaorong. College English teaching students cross-cultural communication ability training [N] Neijiang Technology, 2017, (01): 70-71.

[4] Huang Qing, Yan Xiaoying. Practice and thinking of college English pragmatic competence teaching [J]. English Square, 2016, (05): 84-85.

[5] Wang Rongning. College students' English pragmatic competence teaching research [J]. Journal of Hunan City University (Natural Science Edition), 2016, (02): 233-234.

[6] Gao Xiaohui. College English teaching cross-cultural communication pragmatic failures [J]. Journal of Kaifeng Institute of Education, 2016, (02): 103-104. 